\title{
EDITORIAL
}

\section{Codification: A Civil Law Solution to a Common Law Conundrum?}

\author{
Jonathan Teasdale*
}

The IALS Law Reform Project set about its task some three years ago. Its remit has been - and continues to be - to gain an understanding of the techniques and processes of law reform employed across the world in common law, civil law and mixed law jurisdictions, and to seek (so far as is practicable) to gauge the effectiveness of those mechanisms in delivering law that is perceptibly improved. The project has used a template that is designed to gain wide participation through:

- annual themed workshops held in London (although the co-leaders hope to roll this out to other academic centres in due course)

- the publication of both workshop presentations (in expanded form) and commissioned articles through the EJLR and other academic and practitioner journals

- the maintaining of a series of web pages under the auspices of the Institute of Advanced Legal Studies (as part of the University of London) in the UK

- the fostering of connections with overseas institutes, universities and governmental agencies, leading our European endeavour from the University of Genoa in Italy

- embarking on a review of literature in the law reform field, embracing work from books, periodical articles, reports and commentaries published down the years in both hard copy and electronic form.

The project's second workshop - held in October 2016 - was themed around the subject of legal codification: how it is handled, why it is (or can be) a useful tool, to what applications it can be applied, and why its use is not universal. In civil law jurisdictions codification of statute law, even if not all-embracing, accounts for a significant proportion of a state's legal compass: it provides the bedrock of principles that shape the nation's jurisprudence. In a sense it is the embodiment of the sovereignty of the legislature within the separation of powers: the courts interpret and apply the law but it is not their role to create new law. This, of course, is a broad generalization. But it contrasts starkly with the common law model where the courts not only interpret and apply, but create both substantive and procedural law where (in the view of the judiciary) the courts need to fill gaps in

* Jonathan Teasdale is an associate research fellow at the Institute of Advanced Legal Studies (University of London) in the Sir William Dale Centre for Legislative Studies, and co-leader (with Dr Enrico Albanesi) of the IALS Law Reform Project. He is a barrister (now non-practising) and former lawyer with the Law Commission for England and Wales, and one time was a local authority chief executive. 
statutory law on a case-by-case basis, and then adhere to that law through a doctrine of binding hierarchical precedent. So law, in that model, is derived from two sources: legislative and judicial; and legal principles - sometimes of a very fundamental nature - become part of the overall legal framework. The upside of common law is that it affords the courts the flexibility to develop the law to cater for difficult or previously unknown situations; but the downside is that that development comes about on a piecemeal basis dependent upon the facts and circumstances of individual cases as, and when, they present themselves before the courts.

The consequence of this situation is that although codification, in theory at least, should be the more compelling route in common law jurisdictions so that law can be rationalized and made more accessible, in practice - certainly in the UK - it has failed to grab the attention of policy makers and legislators. Why is this? There are several answers.

First is the argument that once an aspect or aspects of common law are captured within a statutory code, the principles that underpin that particular area of law become entrenched and permit of no variation or exception without further legislative intervention.

Second, that once codes are enacted, they stymie the flexibility, which is an essential element of the common law. If the courts do then seek to create new principles linked to, but outside, the code, the code itself ceases to be the single definitive source of law in the particular field. And by the same token if government seeks to add to the law in the field - as so frequently happens in criminal justice or sentencing or taxation matters - and fails to ensure that the new law is enacted as an integral part of the existing code, the code itself loses its principal benefit: self-containment. These are the juristic dimensions.

Third, there is a political dimension, certainly at Westminster. If a code bill has a very broad remit, and is designed to bring into a single statute large areas of law (for example a criminal or penal code), it will almost certainly comprise a significant number of clauses and schedules. This has two repercussions. Parliamentary time for adequate consideration of the legislation will be considerable, and that will eat into the main legislative programme of the government of the day. Business managers (whips and others) will not welcome the timetabling problems that come with that scenario. And, linked to that concern, will be the fact that a lengthy bill's passage could be held to ransom by opposition filibustering or even "friendly" special pleading for amendments that are only remotely connected to the bill's purpose.

The 2016 workshop was designed as a catalyst for discussion of the differences and similarities that steer civil law and common law jurisdictions down the codification route. And within those jurisdictions the opportunities unlocked through either federalism or legislative devolution (as with Scotland, Wales and Northern Ireland). As one author has put it, when examining the political conditions that prevailed in British India in the nineteenth century (where codification was unrolled by a colonial power on an experimental basis), "It seems to be a historical insight confirmed by the experience of the twentieth century that the less pluralistic and democratic a system, the more easily codification can be achieved", 
and that the antithesis probably holds good. ${ }^{1}$ This is a very debatable suggestion, but at its lowest it helps to demonstrate that political culture drives the shape, and defines the boundaries, of law and law making.

The workshop sought to provide two European perspectives (from Belgium in the North and Italy in the South), both civil law jurisdictions where codification is the norm, and to set those against two common law jurisdictions (the UK and East Africa) where codification initiatives in the fields of criminal and commercial law are employed to achieve both reform and, in the first instance, consolidation and, in the second, harmonization.

Civil law codification has a long and honourable tradition. The Justinian Code (comprising four books) - the first of the major codes - was compiled under the aegis of the Roman emperor and spanned the years AD 529-534. The French (Napoleonic) Civil Code was promulgated in 1804. Both provided foundations for later and more widely adopted codes in Europe and beyond. But in Great Britain the notion of codification of an increasingly sprawling common law, intermingled with statute law, remained for centuries only an idea and an ideal. The statesman Francis Bacon was one of the earliest proponents of a code of English common law in his Proposition Touching the Amendment of the Law published in 1606, and the utilitarian philosopher Jeremy Bentham followed suit in 1817 - during the Age of Enlightenment - by developing abstract theories on common law codification and drafting specimen codes (although these codes were not based specifically on existing common law).

It was not until 1830 onwards that the value of codification was recognized, and then only in the context of overseas possessions. The first Indian codes were enacted post-Rebellion of 1857 when Britain took full governmental control from its then proxy, the East India Company. ${ }^{2}$ Codification also took root across its African territories, so that codes of criminal law and procedure were introduced across swathes of British colonies lying between the Sahara and the Zambesi (viewed initially with deep suspicion by indigenous peoples and settlers alike because of the fear of harsher penalties being imposed). ${ }^{3}$

These first steps in common law codification, taken in part as a means of bringing together English law and those portions of local law that appeared necessary or morally acceptable, used the dependent territories as testing grounds. Back in the metropolis only tentative moves were made to codify specific areas of law rather than whole branches of statute and case law. The Bills of Exchange Act 1882 (drafted by Sir Richard Chalmers) was followed by the Partnership Act 1890 (drafted by Sir Frederick Pollock), the Sale of Goods Act 1893 (Chalmers), the

1 See G.A. Weiss, 'The Enchantment of Codification', Yale Journal of International Law, Vol. 25, 2000, pp. 435, 485.

2 The Code of Civil Procedure 1859 was followed by the Indian Penal Code of 1860, the Code of Criminal Procedure 1861 (subsequently replaced in 1871 and 1882), the Indian Succession Act 1865, the Indian Evidence Act 1872, the Indian Contract Act 1872 and various others (what Weiss said legal comparativists would generally regard as "a system of codified law in the common-law tradition": Ibid., p. 485).

3 See H.F. Morris, 'A History of the Adoption of Codes of Criminal Law and Procedure in British Colonial Africa, 1876-1935', Journal of African Law, Vol. 18, 1974, pp. 6-23. 
Arbitration Act 1889 and the Marine Insurance Act 1906. Then there was a hiatus. World wars, economic depression and reconstruction intervened. In more modern times we really only have the Companies Act 2006 (which was essentially reform linked with restatement) and the Tax Law Rewrite project (in a sense, consolidation-plus), which gave rise to seven separate Acts enacted from 2001 to 2010. ${ }^{4}$

In England and Wales the Law Commission (on its inception) was given a duty, alongside its Scottish counterpart, to keep under review all the law of its jurisdiction with a view to its systematic development and reform, including in particular "codification of such law" together with the elimination of anomalies, the repeal of obsolete and unnecessary enactments, the reduction of separate enactments and generally "the simplification and modernisation" of the law. ${ }^{5}$ This was - and remains - a tall order which the Commission took seriously from the outset. In its First Programme of Law Reform it pledged itself to examine the potential for legal codification in three areas: contract law, landlord and tenant, and family law, albeit that in family law there would be a need for reform before codification could be embarked upon. In 1968 the Second Programme added criminal law as a fourth element. These were extremely ambitious projects, as time would tell. All, barring criminal law, fell by the wayside for a variety of reasons although not without a herculean struggle. The problems were manifold. Codification of existing law alone was seen as inadequate: it was necessary, to create modern law properly fit for purpose, that the existing law from statute and case law sources be identified and examined, and subjected to thorough analysis so that it could be both updated and reformulated. So the process always involved reform before codification became practicable or appropriate. This meant enormous expenditure of time and resources, sometimes to the detriment of other smaller projects in the pipeline.

On top of this there was marked governmental resistance, partly because of the lack of parliamentary time for very large bills, and partly because government had other priorities, particularly in the field of criminal justice. Moreover, the work that was undertaken in the 1980s by both an expert group of academics on producing a criminal code, and then by the Commission, amounted to little more than a restatement of existing law.

However, the extensive and painstaking work undertaken on, for example, family law was not in vain. Instead of aiming for full-scale codification the path was to achieve reform via piecemeal reformulation and codification of specific parts of family law: divorce, matrimonial relief and inheritance. The Children Act 1989 was a major enactment that drew on draft clauses provided by the Law Commission as part of the reform process. The Family Law Act 1996 created a new code of civil remedies for domestic violence; and work on matrimonial property issues continues.

4 Neither of these twenty-first century initiatives can properly be described as codification because they were based on existing statute law rather than an amalgam of statute and case law. 
But none of this amounted to codification as seen in the colonial days or in civil law jurisdictions in continental Europe or across, for example, South America. The question remains, then, whether codification can still find a home in common law countries, such as England and Wales. The devolved government in Wales has expressed interest in making Welsh law easier to find and understand. A major programme to simplify the statute book, and to draw together UK laws that apply particularly to Wales (in areas such as education, health, planning and housing), has been set in motion by the counsel general for Wales. The relatively new legislature wants to "bring order to the laws we have inherited" using a mix of consolidation and codification. The size of the task is not to be underestimated: it will consume time and resources, but in the end will help to bring "clarity" to the legal system. ${ }^{6}$

And the Law Commission is now well into its project to codify sentencing law for England and Wales. Sentencing was one of the four elements that made up the blueprint for the original criminal code. However, when in 2008 the Commission accepted that codification of the criminal law as a whole was no longer a feasible project, it redefined its approach to one of achieving staged simplification of the law as a precursor to codification. The sentencing project was launched in January 2015 under the supervision of commissioner Professor David Ormerod, QC and is making significant headway. A paving bill will be produced in due course to make changes to procedural aspects of sentencing law (the reform of which has been the subject of much commentary by academics and the judiciary alike down the years, given the law's increasing complexity and uncertainty). Once that legislation is in place the codification aim will be achieved through a consolidation exercise bringing together previous statute law plus the latest amendments.

This special issue has an article authored jointly by Professor Ormerod and Harry O'Sullivan, which sets out the underlying need for codification in the sentencing arena and the method by which rationalization can be achieved (focussing on procedural issues and excluding sentencing tariffs because of their political sensitivity). That article is joined by one from Professor Agasha Mugasha of the University of Essex (UK) who, as a former chairman of the Uganda Law Reform Commission, is exceptionally well placed to develop his theme of reform and harmonization of commercial laws across the East African community.

On the civil law side Professor Patricia Popelier of the University of Antwerp provides a Northern Europe perspective on the coordination and codification of law in the Belgian jurisdiction, and the need to balance legal certainty on the one hand (with legal rules that deliver simplicity and sustainability), with legal flexibility on the other, against a background where law is promulgated at both national and regional level. Dr Enrico Albanesi (of the University of Genoa, and co-leader of the IALS project) develops in his article the civil law theme from the viewpoint of law makers in Italy and, in particular, the manner in which legisla-

6 See Welsh Government: New programme to make Welsh law easier to find and understand (13 December 2016), available at <http://gov.wales/newsroom/firstminister/2016/58795099?lang= en> (accessed 18 December 2016). 
tion (including codes) is drafted and given legal status, and the relationship between the legislature and the judiciary when issues arise as to status and legislative interpretation.

In both jurisdictions (Belgium and Italy) codification appears to have started life as a means of creating exhaustive and systematized law. But as the pressures of economic and social change have borne down on the modern states, there is a growing realization that adaptability is valuable for innovation and creativity, and that some form of law reform oversight could be advantageous (alongside the creation of partial "micro codes"). As Professor Popelier has said, codification and its ramifications is "a continuous journey". The question remains: can the UK and other common law countries extract lessons from the civil law jurisdictions' journeys so far, and their likely destinations?

What seems clear is that there is a substantial nexus between consolidation and codification as mechanisms for law reform. And three models might emerge:

a Pure restatement (without reform), within a single legislatively enacted code, of existing law dealing with a particular theme. In civil law jurisdictions that may involve only statute-based law; in common law countries that could be an amalgam of statute law and case law (judicial precedent). ${ }^{7}$

b Limited reform of the relevant existing law, followed by restatement in a single code.

c More complex or far-reaching reform of the relevant law in order to achieve, in a single code, re-ordering, updating and simplification of existing law. ${ }^{8}$

The stance today of the Law Commission in England and Wales - where case law develops daily and where stare decisis (binding precedent) is a key element of judicial decision-making - is to adopt a piecemeal rather than a wholesale approach to codification. Model (b) is, in essence, what we in the UK call consolidation; model (c) amounts to codification. The end product in model (c) is designed to be manageable and to incorporate updating and reform as appropriate. We too are moving towards "mini codes", and maybe there are signs of some confluence between the civil law and common law traditions in the years ahead.

7 The downside of this approach, it is argued by some, is that it ossifies existing imperfections in the law and leaves gaps demanding further legislative or judicial intervention at a later date.

8 The downside of this approach is that, at a political level, the draft legislation could give rise to parliamentary contention, protracted debate and consequential delay. 